\title{
Removal of Cresols From Water by Packed Beds of Cyclodextrin-Based Hydrogels
}

\author{
Francisco J. Peñas ${ }^{1}\left[\right.$ [ . Ana Romo ${ }^{1}$ José R. Isasi ${ }^{1}$
}

Accepted: 3 August 2021 / Published online: 26 August 2021

(c) The Author(s) 2021

\begin{abstract}
A cyclodextrin-based polymer was prepared by crosslinking $\beta$-cyclodextrin with epichlorohydrin to be assessed as a sorbent material for cresols in packed-bed columns. Both Langmuir and Freundlich isotherms were appropriate to describe the sorption equilibrium in the conditions tested, and the thermodynamic parameters obtained for this process confirmed its exothermic nature with similar enthalpies (between -6.8 and $-8.3 \mathrm{~kJ} / \mathrm{mol}$ ) for the three isomers. The removal of cresols from water was carried out in nine cycles of sorption-desorption in fixed-column experiments with the cyclodextrin hydrogel, achieving sorption capacities of $6.2,11.6$, and $15.1 \mathrm{mg} / \mathrm{g}$ for $o-, m-, p$-cresol, respectively. These differences in sorption capacities are due to the different chemical structures of cresols, that is, the relative position of the methyl and hydroxyl groups. However, similar sorption rates were observed for each isomer, with a mean value of $0.10 \mathrm{mg}$-cresol g-CDP-1 $\mathrm{min}^{-1}$ in all cases. The experimental data for the breakthrough and the elution curves have been successfully modeled by two effective two-parameter equations, a dose-response model for the sorption step and a pulse-peak model for the regeneration step. The cyclodextrin polymer matrix has been proven to be an effective a good sorbent material for removing cresols from water, exhibiting remarkable reusability performance and structural stability throughout the successive elution steps carried out with methanol.
\end{abstract}

Keywords Cresol · Cyclodextrin polymer · Adsorption · Thermodynamic parameters · Breakthrough curve · Elution curve · Kinetic modeling

\section{Introduction}

Adsorption is a mass transfer operation, included among the advanced (or tertiary) treatment technologies, applied to wastewater treatment and water purification usually to remove refractory pollutants. Through adsorption, certain constituents in the aqueous phase are transferred to the solid interface where they are retained, thus improving effluent quality. Therefore, the development of more selective adsorbents with high sorption capacities and good reusability properties is a matter of interest [1].

In particular, cyclodextrin-based hydrogels are synthetic polymeric adsorbents that have been extensively tested for this purpose [2-4]. Cyclodextrins (CDs) are cyclic oligosaccharides with already recognized capability as sorbents

Francisco J. Peñas

jpesteban@unav.es

1 Department of Chemistry, University of Navarra, 31009 Pamplona, Spain due to their amphiphilic nature by presenting a structure with a relatively hydrophobic cavity and hydrophilic edges. This makes CDs potentially useful for selective removal contaminants from water. On the other hand, given their high solubility in water, CDs are cross-linked into water-insoluble cyclodextrin-based polymers (CDPs) to enhance their usability for water treatment. For instance, taking advantage of the good sorption properties of CDs to dampen inhibitory effects by shock-loading events, CDP hydrogels have also been used as carrier particles for attached-growth of phenol-degrading bacteria in bioreactors $[5,6]$. The uses of cyclodextrin crosslinked polymers as sorbents of aromatic compounds have been known for years $[4,7]$ and their application to the treatment of phenolic resin plant wastewaters has also been previously reported [8]. Recently an excelent review on recent developments of cyclodextrin-based materials has been published [9]. However, most studies refer to batch applications, but relatively few addressing the reusability of CDPs in adsorbers with continuous influent flow [10]. Even though some other affordable materials, such as 
coconut charcoal, might show a better adsorption performance, this investigation demonstrates that these hydrogel sorbents are stable through successive sorption-desorption cycles.

The present work addresses the performance of a CDP applied for the removal of cresols from water in several cycles of sorption-desorption in fixed-column experiments. Cresols are methylated derivatives of phenol which include three isomers: 2-methylphenol (ortho-cresol, o-cresol), 3-methylphenol (meta-, $m$-), and 4-methylphenol (para-, $p$-). As other phenolic compounds, cresols are extensively used as organic reagents in different manufacturing industries, and their discharge to the aquatic environment is a matter of concern [11]. The breakthrough curves measured for each isomer are well described by a dose-response model, whereas a pulse-peak model fits adequately the corresponding regeneration profiles obtained by elution with methanol. In addition, the sorption equilibrium data of $o-, m$ - and $p$-cresol on the CDP have been fitted to the Freundlich and Langmuir isotherm models and the thermodynamic parameters of these processes have been calculated.

\section{Materials and Methods}

\section{Reagents and Analytical Methods}

$\beta$-Cyclodextrin (99\%) was supplied by Roquette-Laisa (Spain). Epichlorohydrin (99\%), $o$-cresol (99\%), $m$-cresol (99\%), p-cresol (99\%) and sodium hydroxide (97\%) were provided by Sigma-Aldrich (Germany). Solvent-grade methanol (99.5\%) was purchased from Panreac (Spain), and HPLC-grade methanol (99.99\%) was from Scharlau (Spain). Sodium tetrahydroborate $(96 \%)$ and paraffin oil were also from Panreac (Spain). All reagents were used as received.

Cresols were determined by UV-vis spectrophotometry (HP 8452A, USA) using a diode-array detector. Absorbance measurements were made at 270,272 , and $278 \mathrm{~nm}$ for $o^{-}$, $m$ - and $p$-cresol, respectively.

\section{Sorbent}

A cyclodextrin-based polymer (CDP) was tested as a sorbent for $o-, m$ - and $p$-cresol in packed-bed experiments. Practically spherical particles of CDP hydrogel were prepared by oil-water suspension polymerization, using a CD:epichlorohydrin molar ratio of 11:1 (feed basis), according to method described by Romo et al. [12]. The swelling capacity of CDP was $5.1 \mathrm{~g}$-water/g-dry gel, whereas a composition of $58.0 \mathrm{wt}$.\% of cyclodextrin (measured by CHN elemental analysis). Previous characterization of this CDP hydrogel gave a swollen particle density of $1055 \mathrm{~g} / \mathrm{L}$, that is, a bulk density of $765 \mathrm{~g} / \mathrm{L}$ for a bed voidage of $27.5 \%$ [10].
The CDP beads were wet sieved to separate the fraction used in this study, with a particle size range of $1.00-1.25 \mathrm{~mm}$.

\section{Sorption Isotherms}

Batch experiments at natural $\mathrm{pH}$ (about 6.6) were carried out to determine the sorption isotherms of the three cresols by $\mathrm{CDP}$ at $15,25,35$ and $45^{\circ} \mathrm{C}$. To this end, known amounts of dry CDP particles (from 20 to $250 \mathrm{mg}$ ) were added to $50 \mathrm{~mL}$ of aqueous solutions of cresols with different initial concentrations. Amber glass bottles (Supelco, $2 \mathrm{fl} \mathrm{oz}$, USA) with septum-sealed caps (Supelco, Mininert valve, USA) were used. The systems were kept stirred for $3 \mathrm{~h}$ (Velp Scientifica, Multistirrer 15, Italy) inside a 150-L insulated chamber with forced-air heating and temperature control (Crouzet, CTD43, France). Preliminary kinetic tests (data not showed) indicated that equilibrium was achieved in less than one hour in all cases.

Once equilibrium was reached, the remaining cresol was analyzed in each supernatant, and the sortion capacity $(q)$ calculated as follows:

$q=V\left(C_{0}-C *\right) / W_{C D P}$

where $V$ was the volume of aqueous solution, $W_{\mathrm{CDP}}$ the dry weight of sorbent, and $C_{0}$ and $C^{*}$ the initial and equilibrium concentrations of cresol, respectively.

Experimental data were then fitted (OriginLab Corp, OriginPro 8.5, USA) to the isotherm models of Freundlich and Langmuir (Eqs. 2 and 3, respectively).

$q=K_{F} C *^{1 / n}$

$q=K_{L} q_{M} C * /\left(1+K_{L} C *\right)$

where $K_{\mathrm{F}}$ and n were the parameters of Freundlich isotherm, and $K_{\mathrm{L}}$ and $q_{\mathrm{M}}$ the Langmuir ones.

From the relationship between equilibrium and thermodynamics, the sorption equilibrium constant $\left(K_{\mathrm{S}}\right.$, dimensionless) can be expressed as follows:

$\ln K_{S}=\ln \left(\rho_{W} q / C *\right)=-\Delta G^{0} / R T=-\Delta H^{0} / R T+\Delta S^{0} / R$

where $\rho_{\mathrm{W}}$ is water density at each temperature. Hence, experimental data were fitted to Eq. (4) to determine the sorption thermodynamic parameters for each sorbate: enthalpy $\left(\Delta H^{0}\right)$, entropy $\left(\Delta S^{0}\right)$, and free energy $\left(\Delta G^{0}\right)$.

\section{Sorption-desorption experiments}

Three packed bed columns (Supelco, Omnifit 15-mm glass column, USA) were operated in an isothermal chamber at $25 \pm 1^{\circ} \mathrm{C}$. Each column was filled with $1.700 \pm 0.002 \mathrm{~g}$ 
of hydrogel (dry basis), which yielded a bed height of about $75 \mathrm{~mm}$ after swelling of CDP beads (bulk density $765 \mathrm{~g}$-swollen gel/L, bed voidage 0.275 ). A previous preparation of the each bed was carried out by flowing deionized water through the columns to allow the equilibrium swelling of CDP particles. Separate stock solutions $(1.0 \mathrm{mmol} / \mathrm{L})$ were used as influent feed, one for each cresol and column. Each so-prepared influent was delivered by a multichannel peristaltic pump (Masterflex L/S Cole Palmer, USA) at a flow rate of $2.60 \mathrm{~mL} / \mathrm{min}$ (i.e. hydraulic residence time $5.10 \mathrm{~min}$ ) through each bed. The experiments were performed at the natural $\mathrm{pH}$ of the cresol solutions. In each operating cycle, once sorbent saturation was achieved, beds were regenerated by elution with methanol at a flow-rate of $2.60 \mathrm{~mL} / \mathrm{min}$. Methanol had already shown better performance than ethanol and isopropanol in the regeneration of phenol-saturated CDP beds [10]. Effluent samples were periodically collected from each column and stored in glass vials until further analysis.

\section{Modeling of breakthrough and elution curves}

The breakthrough and elution profiles were described as a function of time $(t)$ by a dose-response curve (Eq. 5) and a pulse-peak model (Eq. 6), respectively.

$C_{0} / C=1+\left(t_{1 / 2} / t\right)^{b}$

$C / C_{0}=k \exp (-c t)\left[1-\exp \left(-d t^{2}\right)\right]$

being $C$ the concentration of cresol in the effluent; $C_{0}$ the concentration at time zero; $t_{1 / 2}$ the time needed for $C$ to become equal to $C_{0} / 2 ; b$ the sharpness coefficient; and $k$, $c$ and $d$ are fitting parameters. Therefore, a two-parameter equation is assumed for breakthrough curves, and a threeparameter model for regeneration curves. However, considering the mass conservation law for both steps of adsorption (Eq. 7) and desorption (Eq. 8), a boundary condition can be applied to fix $k$ so that Eq. (6) finally has two independent adjustable parameters $(c$ and $d$ ).

$W_{1}=Q_{1} \int_{0}^{\infty}\left(C_{0}-C\right) d t=C_{0} t_{1 / 2}^{b} Q_{1} \int_{0}^{\infty} \frac{d t}{t^{b}+t_{1 / 2}^{b}}$

$W_{2}=k Q_{2} C_{0}\left\{\frac{1}{c}+\frac{1}{2} \sqrt{\frac{\pi}{d}} \exp \left(\frac{c^{2}}{4 d}\right)\left[\operatorname{erf}\left(\frac{c}{2 d^{0.5}}\right)-1\right]\right.$

where $W_{1}$ and $W_{2}$ are the amounts of cresol adsorbed and desorbed, respectively; and $Q_{1}$ and $Q_{2}$ the influent and elutant flow rates, respectively.

The quality of the proposed models was assessed by multiple nonlinear regression analysis by minimizing the residuals between the experimental and predicted values. The standard errors of the estimate (SSE) were calculated according to:

$S S E=\left[\sum\left(Y_{\text {calculated }}-Y_{\text {exp erimental }}\right)^{2} /(N-2)\right]^{1 / 2}$

where $N$ is the number of data used (in fact, $N-2$ represents the number of degrees of freedom for each analysis model). A detailed description of the modeling approach can be found in Peñas et al. [10].

\section{Results and Discussion}

\section{Sorption isotherms}

The Freundlich and Langmuir isotherms (Eqs. 2 and 3, respectively), the most-widely used models, were employed to describe the sorption equilibrium data of cresols onto the CDP beads. The best-fitted parameters obtained in the batch assays are listed in Table 1 for both models, and the standard errors of the estimate (SSE) have also been included for comparison. Standard errors are indicated in parentheses where applicable. In general, a very acceptable fit was obtained with both models. Interestingly, Rekharsky and Inoue [13] reported virtually equal values for the inclusion complexation of $p$-cresol with $\beta$-cyclodextrin (1:1 molar ratio) at $25^{\circ} \mathrm{C}$.

As representative examples, Fig. 1 shows the experimental equilibrium data from the batch sorption experiments at the two lowest temperatures assayed $\left(15\right.$ and $\left.25^{\circ} \mathrm{C}\right)$. The respective solid curves were calculated by applying the corresponding isotherm models (Eq. 2 and 3, respectively), and are included to illustrate the quality of the fit. The same trend was observed for the other temperatures. For each individual cresol, a joint representation of the four isotherms leads to a confusing graph, with data points very close to each other, so this type of graph has been omitted.

The Langmuir parameter $q_{\mathrm{M}}$ represents the theoretical maximum amount of sorbate per unit mass of sorbent forming a complete monolayer, and is related to the maximum sorption capacity of the solid. As observed, for each temperature in the tested conditions, this maximum capacity was higher with $p$-cresol than with $m$-cresol, and this in turn was higher than that of $o$-cresol. According to our experimental results (not shown), the $\beta-\mathrm{CD} /$ cresols interaction constants at $25^{\circ} \mathrm{C}$ (values in $\mathrm{L} / \mathrm{mol}$ ) vary in the order: $K_{o \text {-cresol }}(400)>K_{p \text {-cresol }}(200)>K_{m \text {-cresol }}(125)$. Nevertheless, in addition to the host-guest inclusion complexation, these sorbates can also establish other interactions with the crosslinked networks. Thus, it is shown that there is some synergistic behaviour when both are 
Table 1 Isotherm parameters for Freundlich and Langmuir models for adsorption equilibrium data of cresols onto the CDP matrix

\begin{tabular}{|c|c|c|c|c|}
\hline$o$-Cresol & $15^{\circ} \mathrm{C}$ & $25^{\circ} \mathrm{C}$ & $35^{\circ} \mathrm{C}$ & $45^{\circ} \mathrm{C}$ \\
\hline$K_{\mathrm{F}}\left(\mathrm{mg}^{1-1 / \mathrm{n}} \mathrm{L}^{-\mathrm{n}} \mathrm{g}^{-1}\right)$ & $0.248(0.012)$ & $0.190(0.038)$ & $0.231(0.023)$ & $0.175(0.019)$ \\
\hline$n$ & $1.21(0.03)$ & $1.19(0.10)$ & $1.21(0.05)$ & $1.18(0.05)$ \\
\hline $\operatorname{SSE}_{\text {Freundlich }}\left(\mathrm{mg} \mathrm{g}^{-1}\right)$ & 0.0479 & 0.1429 & 0.0926 & 0.0837 \\
\hline $\mathrm{R}_{\text {Freundlich }}^{2}$ & 0.9982 & 0.9742 & 0.9891 & 0.9904 \\
\hline$K_{\mathrm{L}} \times 10^{3}\left(\mathrm{~L} \mathrm{mg}^{-1}\right)$ & $17.9(2.5)$ & $13.2(7.3)$ & $23.9(5.4)$ & $21.1(6.9)$ \\
\hline$q_{\mathrm{M}}\left(\mathrm{mg} \mathrm{g}^{-1}\right)$ & $11.2(1.2)$ & $11.4(5.2)$ & $8.25(1.34)$ & $7.42(1.77)$ \\
\hline $\operatorname{SSE}_{\text {Langmuir }}\left(\mathrm{mg} \mathrm{g}^{-1}\right)$ & 0.0520 & 0.1151 & 0.0870 & 0.1135 \\
\hline $\mathrm{R}_{\text {Langmuir }}^{2}$ & 0.9979 & 0.9833 & 0.9904 & 0.9824 \\
\hline$m$-Cresol & $15^{\circ} \mathrm{C}$ & $25^{\circ} \mathrm{C}$ & $35^{\circ} \mathrm{C}$ & $45^{\circ} \mathrm{C}$ \\
\hline$K_{\mathrm{F}}\left(\mathrm{mg}^{1-1 / \mathrm{n}} \mathrm{L}^{-\mathrm{n}} \mathrm{g}^{-1}\right)$ & $0.253(0.033)$ & $0.253(0.022)$ & $0.213(0.038)$ & $0.270(0.049)$ \\
\hline$n$ & $1.17(0.06)$ & $1.18(0.04)$ & $1.18(0.09)$ & $1.27(0.11)$ \\
\hline $\operatorname{SSE}_{\text {Freundlich }}\left(\mathrm{mg} \mathrm{g}^{-1}\right)$ & 0.1392 & 0.0961 & 0.1393 & 0.1275 \\
\hline $\mathrm{R}_{\text {Freundlich }}^{2}$ & 0.9902 & 0.9938 & 0.9848 & 0.9841 \\
\hline$K_{\mathrm{L}} \times 10^{3}\left(\mathrm{~L} \mathrm{mg}^{-1}\right)$ & $18.9(5.5)$ & $18.1(4.5)$ & $19.4(7.2)$ & $25.6(15.1)$ \\
\hline$q_{\mathrm{M}}\left(\mathrm{mgg}^{-1}\right)$ & $12.5(2.7)$ & $12.1(2.3)$ & $10.0(2.8)$ & $8.04(3.34)$ \\
\hline $\operatorname{SSE}_{\text {Langmuir }}\left(\mathrm{mg} \mathrm{g}^{-1}\right)$ & 0.1339 & 0.1058 & 0.1147 & 0.1650 \\
\hline $\mathrm{R}_{\text {Langmuir }}^{2}$ & 0.9909 & 0.9924 & 0.9896 & 0.9733 \\
\hline$p$-Cresol & $15^{\circ} \mathrm{C}$ & $25^{\circ} \mathrm{C}$ & $35^{\circ} \mathrm{C}$ & $45^{\circ} \mathrm{C}$ \\
\hline$K_{\mathrm{F}}\left(\mathrm{mg}^{1-1 / \mathrm{n}} \mathrm{L}^{-\mathrm{n}} \mathrm{g}^{-1}\right)$ & $0.316(0.024)$ & $0.399(0.020)$ & $0.412(0.050)$ & $0.288(0.031)$ \\
\hline$n$ & $1.06(0.04)$ & $1.21(0.03)$ & $1.26(0.08)$ & $1.22(0.07)$ \\
\hline $\operatorname{SSE}_{\text {Freundlich }}\left(\mathrm{mg} \mathrm{g}^{-1}\right)$ & 0.0894 & 0.0686 & 0.1577 & 0.0854 \\
\hline $\mathrm{R}_{\text {Freundlich }}^{2}$ & 0.9956 & 0.9960 & 0.9810 & 0.9925 \\
\hline$K_{\mathrm{L}} \times 10^{3}\left(\mathrm{Lmg}^{-1}\right)$ & $27.3(8.4)$ & $26.3(7.1)$ & $28.9(13.4)$ & $26.4(7.5)$ \\
\hline$q_{\mathrm{M}}\left(\mathrm{mgg}^{-1}\right)$ & $13.2(3.2)$ & $13.0(2.8)$ & $11.6(4.1)$ & $9.42(2.06)$ \\
\hline $\operatorname{SSE}_{\text {Langmuir }}\left(\mathrm{mg} \mathrm{g}^{-1}\right)$ & 0.1234 & 0.1023 & 0.1822 & 0.0787 \\
\hline $\mathrm{R}_{\text {Langmuir }}^{2}$ & 0.9916 & 0.9911 & 0.9746 & 0.9937 \\
\hline
\end{tabular}

Fig. 1 Experimental data and calculated isotherms for sorption equilibrium of cresols onto the CDP matrix: a Freundlich model at $15^{\circ} \mathrm{C}$, b Langmuir model at $25^{\circ} \mathrm{C}$
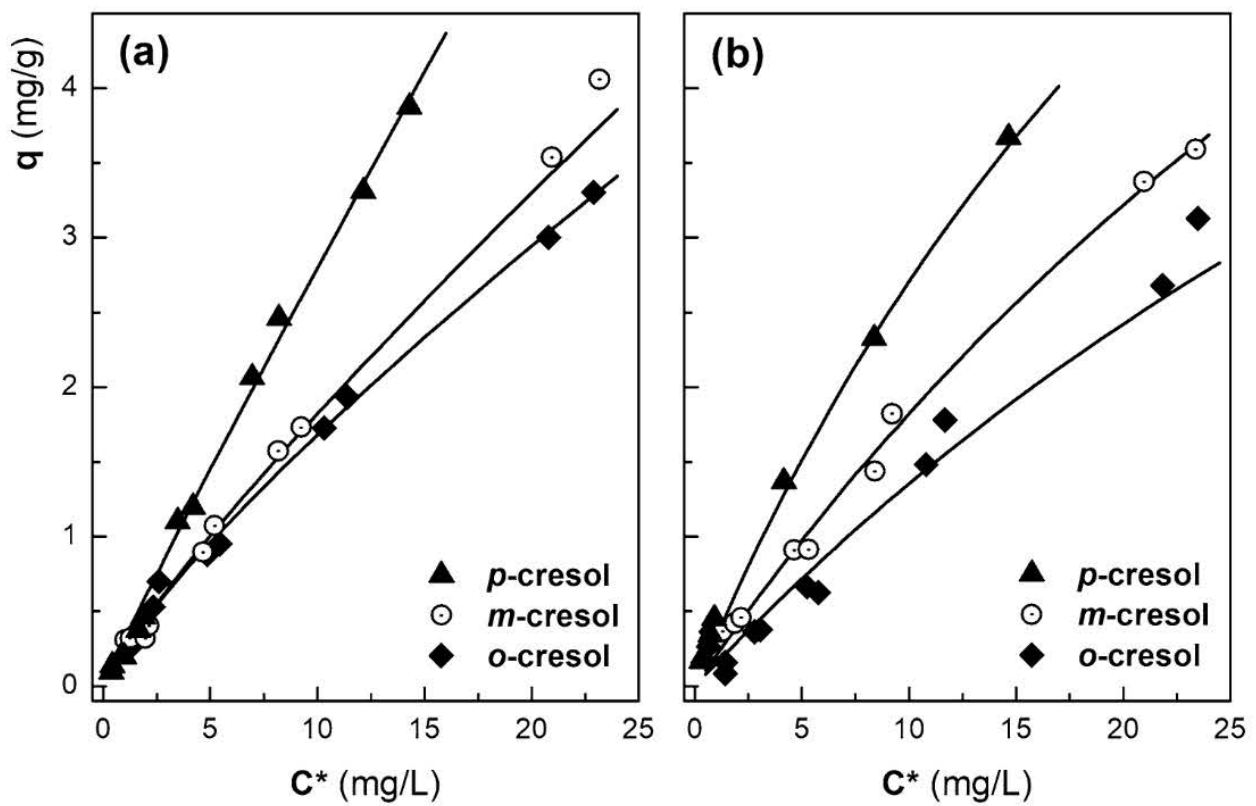

considered. As is well known, aromatic molecules and residues can be encapsulated within cyclodextrin rings. For instance, the formation of a host-guest inclusion complex between $m$-cresol into the hydrophobic cavity of $\beta$-CD with 1:1 stoichiometry has been recently confirmed by several experimental techniques [14]. Nevertheless, the 
interactions of such phenolic sorbates with the hydrogel crosslinked networks (also known as 'secondary' cavities) by means of hydrogen bonding cannot be discarded either [15]. The decreasing trend in the $q_{\mathrm{M}}$ values with rise in temperature is consistent with the exothermic nature of the sorption process of cresols onto CDP matrices [15]. Likewise, the sorption thermodynamic parameters obtained from Eq. (4), summarized in Table 2, confirm the spontaneity of this process and also its exothermic nature. As observed, the corresponding values are very close to each other, showing few differences between them. These results are quantitatively similar to those reported for the adsorption of cresols on polymeric resin adsorbents [16].

\section{Sorption Experiments}

The experimental data for the breakthrough curves obtained for the sorption of cresols onto the CDP beds were satisfactorily fitted to the dose-response model. The corresponding fitting parameters are listed in Table 3 for the nine cycles performed for each cresol. In addition, the amount of retained sorbate is obtained from Eq. (7). As observed, acceptable fit to Eq. (5) was achieved in all systems (calculated determination coefficients, $\mathrm{R}^{2}>0.99$ ).

As a thumb rule, for each cresol, the fitting parameters $\left(t_{1 / 2}\right.$ and $\left.b\right)$ exhibited a slight decreasing trend as cycle number increases. The calculated $t_{1 / 2}$ values for $o$-cresol
Table 2 Thermodynamic parameters for the adsorption of cresols on the CDP matrix

\begin{tabular}{|c|c|c|c|c|c|c|c|c|}
\hline \multirow[t]{2}{*}{ Sorbate } & \multirow[t]{2}{*}{$\Delta \mathrm{H}^{\circ}\left(\mathrm{kJ} \mathrm{mol}^{-1}\right)$} & \multirow{2}{*}{$\begin{array}{l}\Delta \mathrm{S}^{\circ}(\mathrm{J} \\
\left.\mathrm{mol}^{-1} \mathrm{~K}^{-1}\right)\end{array}$} & \multicolumn{4}{|c|}{$\Delta \mathrm{G}^{\circ}\left(\mathrm{kJ} \mathrm{mol}^{-1}\right)$} & \multirow[t]{2}{*}{$\operatorname{SSE}\left(\mathrm{mol} \mathrm{g}^{-1}\right)$} & \multirow[t]{2}{*}{$\mathrm{R}^{2}$} \\
\hline & & & $15^{\circ} \mathrm{C}$ & $25^{\circ} \mathrm{C}$ & $35^{\circ} \mathrm{C}$ & $45^{\circ} \mathrm{C}$ & & \\
\hline$o$-Cresol & -7.20 & 16.6 & -12.0 & -12.2 & -12.3 & -12.5 & $1.53 \cdot 10^{-6}$ & 0.9714 \\
\hline$m$-Cresol & -6.75 & 19.6 & -12.4 & -12.6 & -12.8 & -13.0 & $1.69 \cdot 10^{-6}$ & 0.9737 \\
\hline$p$-Cresol & -8.31 & 18.1 & -13.5 & -13.7 & -13.9 & -14.1 & $1.81 \cdot 10^{-6}$ & 0.9716 \\
\hline
\end{tabular}

\begin{tabular}{|c|c|c|c|c|c|c|}
\hline Run & $C_{0}(\mathrm{mg} / \mathrm{L})$ & $t_{1 / 2}(\min )$ & $b(-)$ & $W_{1}(\mathrm{mg})$ & SSE (-) & $\mathrm{R}^{2}$ \\
\hline oC1 & 106.7 & 32.07 & 3.083 & 10.6 & 0.0274 & 0.9955 \\
\hline oC2 & 108.5 & 31.75 & 3.048 & 10.8 & 0.0250 & 0.9960 \\
\hline oC3 & 106.3 & 30.67 & 2.805 & 10.5 & 0.0174 & 0.9979 \\
\hline oC4 & 105.4 & 30.50 & 2.802 & 10.4 & 0.0208 & 0.9968 \\
\hline oC5 & 105.4 & 29.70 & 2.609 & 10.5 & 0.0301 & 0.9930 \\
\hline oC6 & 109.2 & 30.51 & 2.969 & 10.5 & 0.0224 & 0.9967 \\
\hline oC7 & 108.1 & 29.83 & 2.726 & 10.7 & 0.0171 & 0.9979 \\
\hline oC8 & 108.1 & 30.29 & 2.849 & 10.5 & 0.0137 & 0.9986 \\
\hline oC9 & 109.7 & 30.43 & 2.792 & 10.7 & 0.0197 & 0.9970 \\
\hline $\mathrm{mC} 1$ & 112.5 & 59.75 & 3.309 & 20.4 & 0.0271 & 0.9942 \\
\hline $\mathrm{mC} 2$ & 113.9 & 58.82 & 3.308 & 20.3 & 0.0186 & 0.9975 \\
\hline $\mathrm{mC} 3$ & 112.6 & 60.14 & 3.372 & 20.4 & 0.0212 & 0.9969 \\
\hline $\mathrm{mC} 4$ & 111.8 & 59.60 & 3.329 & 20.2 & 0.0234 & 0.9961 \\
\hline $\mathrm{mC} 5$ & 107.0 & 60.63 & 3.366 & 19.6 & 0.0251 & 0.9957 \\
\hline mC6 & 105.3 & 60.77 & 3.474 & 19.1 & 0.0202 & 0.9973 \\
\hline $\mathrm{mC7}$ & 106.7 & 59.97 & 3.350 & 19.3 & 0.0294 & 0.9945 \\
\hline $\mathrm{mC} 8$ & 107.2 & 60.13 & 3.197 & 19.8 & 0.0184 & 0.9976 \\
\hline $\mathrm{mC} 9$ & 105.9 & 58.30 & 3.185 & 18.9 & 0.0270 & 0.9948 \\
\hline $\mathrm{pC} 1$ & 110.2 & 77.16 & 3.082 & 26.4 & 0.0227 & 0.9949 \\
\hline $\mathrm{pC} 2$ & 103.4 & 79.25 & 2.684 & 26.9 & 0.0233 & 0.9947 \\
\hline $\mathrm{pC} 3$ & 103.4 & 80.40 & 2.623 & 27.6 & 0.0236 & 0.9946 \\
\hline $\mathrm{pC} 4$ & 105.6 & 77.22 & 2.760 & 26.5 & 0.0187 & 0.9972 \\
\hline $\mathrm{pC} 5$ & 105.6 & 71.65 & 2.688 & 24.9 & 0.0058 & 0.9997 \\
\hline pC6 & 107.7 & 69.27 & 2.623 & 24.8 & 0.0076 & 0.9996 \\
\hline pC7 & 104.2 & 66.70 & 2.290 & 24.9 & 0.0130 & 0.9986 \\
\hline $\mathrm{pC} 8$ & 107.8 & 63.76 & 2.262 & 24.8 & 0.0186 & 0.9968 \\
\hline $\mathrm{pC} 9$ & 107.8 & 63.82 & 2.237 & 24.9 & 0.0138 & 0.9984 \\
\hline
\end{tabular}

$o C o$-cresol, $m C m$-cresol, $p C p$-cresol
Table 3 Fitting parameters of breakthrough curves (test runs 1 to 9) of cresols on the CDP matrix 
(average $30.6 \pm 0.8 \mathrm{~min}$ ) were significantly lower than those for $m$-cresol $(59.6 \pm 0.8 \mathrm{~min})$ and these in turn lower than those for $p$-cresol $(72.1 \pm 6.5 \mathrm{~min})$. This implies that the CDP matrix becomes saturated first with $o$-cresol, then with $m$-cresol, and finally with $p$-cresol. However, this does not mean that the sorption kinetics become faster for the former or, consequently, slower for the latter. It should be noted that the amounts sorbed in each cycle were low for $o$-cresol (average $10.6 \pm 0.1 \mathrm{mg}$ ), medium for $m$-cresol $(19.8 \pm 0.6 \mathrm{mg})$, and higher for $p$-cresol $(25.7 \pm 1.1 \mathrm{mg})$. Thus, the average sorption capacities of the isomers in these experimental conditions were $6.2 \pm 0.1 \mathrm{mg} / \mathrm{g}$ CDP for $o$-cresol, $11.6 \pm 0.3 \mathrm{mg} / \mathrm{g}$ for $m$-cresol, and $15.1 \pm 0.6 \mathrm{mg} / \mathrm{g}$ for $p$-cresol. In fact, keeping in mind that $t_{1 / 2}$ represents the half time to reach sorbent saturation, the average sorption rate (estimated as $1 / 2 W_{\text {ads }} t_{1 / 2}{ }^{-1}$ ) reached a very similar value in the three cases $(0.172,0.166$, and $0.178 \mathrm{mg} / \mathrm{min}$ for $o-, m$-, and $p$-cresol, respectively). In other words, a strong correlation between $t_{1 / 2}$ and $W_{\text {ads }}$ was found $\left(\mathrm{R}^{2}=0.9888\right)$. This can be explained by considering that the isomers present practically the same molecular volume, $0.1088 \pm 0.0003 \mathrm{~nm}^{3}$ [17], and the available sorption sites of the CDP bed do not change during the experiments. Therefore, once the most accessible external sites are occupied, molecular diffusion through the CDP matrix is easier for $p$-cresol than for $o$-cresol due to their respective molecular structures (the relative position of methyl and hydroxyl groups) and, at the same time, more sites are suitable for the sorption. Note that the effective diameters of cresols are of the same order (slightly higher) than that of $\beta-C D$ cavities.

Representative examples of the experimental data and the predicted breakthrough curves (calculated from Eq. 5) are shown in Fig. 2. No significant differences were observed from test run 1 to 9 with each sorbate used. The good reusability of the CDP sorbent is evidenced for $m$-cresol (Fig. 2a) with three different sorption cycles (test runs 1, 5, and 9). The effect of the sorbent-sorbate interaction is visualized (Fig. 2b) for the same operating cycle (test run 3). Similar trends were found for each cresol and for each test run performed.

There is relatively few research on sorption of cresols in fixed-bed columns. A comparative of maximum sorption capacities for several adsorbents towards cresols is listed in Table 4. All of the references included, except that concerning this study, were performed in batch systems. It can be observed that large differences are found in the experimental conditions applied by each case. Likewise, El Naas et al. [33] reported adsorption capacities up to $63 \mathrm{mg}$ of total phenols per gram of a granular activated carbon when studying the removal of phenols from an oil refinery wastewater in fixedbed column experiments at $25^{\circ} \mathrm{C}$. Unfortunately, aggregate values are given for all phenols present in the industrial
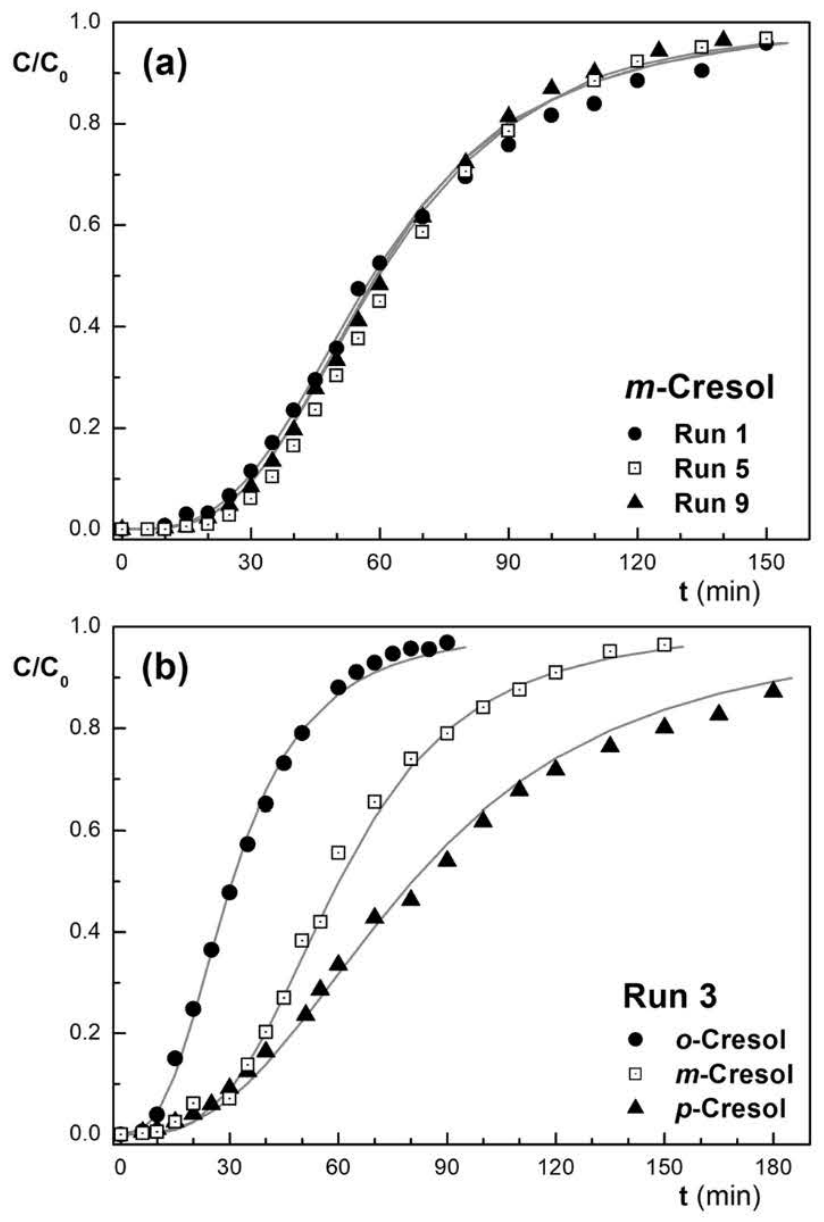

Fig. 2 Breakthrough curves for sorption of cresols onto CDP beds: a for $m$-cresol sorption in test runs 1,5 and 9 ; $\mathbf{b}$ for the three isomers at test run 3

effluent treated, but specific figures for each compound are not available.

In addition, experimentation with repeated adsorption cycles is less common. For instance, the retention of $p$-cresol on two different modified vermiculites, even while achieving good initial sorption capacities, showed a marked decrease in reusability after only three cycles of use [27]. After four cycles of regeneration with an ethanol/acetic acid solution, the adsorption capacity of imprinted nanocomposites from biomass bacterial cellulose was reduced to $10 \%$ for $o$-cresol and about 6-7\% for $m$-cresol and $p$-cresol [23].

On the other hand, in view of the scarcity of works with cresols and cyclodextrin-based sorbents, it is interesting to point out some recent studies on phenol adsorption on these type of materials. Thus, Peng et al. reported a maximum adsorption capacity for phenol of $36.0 \mathrm{mg} / \mathrm{g}$ with a modified $\beta$-cyclodextrin chitosan composite in batch sorption assays at $25{ }^{\circ} \mathrm{C}$ and $\mathrm{pH} 6$ [34]. A sorption capacity of $29.6 \mathrm{mg}$ of phenol per gram of sorbent was reached in a packedbed filled with a similar CDP treating a synthetic phenolic 
Table 4 Maximum sorption capacities for cresols onto different adsorbents

\begin{tabular}{|c|c|c|c|c|c|}
\hline Adsorbent & Cresol & $C_{0, \operatorname{MAX}}(\mathrm{mg} / \mathrm{L})$ & $q_{\mathrm{MAX}}(\mathrm{mg} / \mathrm{g})$ & $\mathrm{T}\left({ }^{\circ} \mathrm{C}\right)$ & References \\
\hline Commercial activated carbon & $o-$ & 200 & 36.0 & 30 & [18] \\
\hline Commercial activated carbon & $p$ - & 70 & 56.6 & 25 & [19] \\
\hline Cork activated carbon & $p-$ & 4,900 & 340 & 25 & {$[20]$} \\
\hline Sawdust activated carbon & $o-$ & 500 & 222 & 25 & [21] \\
\hline $\mathrm{Al}_{2} \mathrm{O}_{3} /$ carbon nanotubes & $p-$ & 200 & 70.4 & & {$[22]$} \\
\hline Commercial alumina & $p$ - & 70 & 55.8 & 25 & [19] \\
\hline Bacterial cellulose film & $o-$ & 600 & 23.7 & 25 & [23] \\
\hline Bacterial cellulose film & $m-$ & 600 & 33.9 & 25 & {$[23]$} \\
\hline Bacterial cellulose film & $p-$ & 600 & 45.6 & 25 & {$[23]$} \\
\hline Coconut charcoal & $p$ - & 1,000 & 257 & 25 & [24] \\
\hline Diatomite/carbon composite & $p$ - & 120 & 82 & RT & [25] \\
\hline Synthetic hydroxyapatite & $p-$ & 346 & 67.6 & & [26] \\
\hline Modified vermiculite & $p-$ & 200 & 59.7 & 25 & [27] \\
\hline Nanocomposite hydrogel & $m-$ & 250 & 176 & 35 & {$[28]$} \\
\hline Commercial resin & $o-$ & 1000 & 173 & 20 & [16] \\
\hline Commercial resin & $m-$ & 1000 & 195 & 20 & {$[16]$} \\
\hline Commercial resin & $p-$ & 1000 & 195 & 20 & [16] \\
\hline Commercial resin & $p-$ & 600 & 141 & 20 & [29] \\
\hline Rhamnolipid composite & $p-$ & 40 & 25 & 20 & {$[30]$} \\
\hline$\beta-\mathrm{CDP}$ & $m-$ & 60 & 5.0 & 20 & {$[31]$} \\
\hline$\beta-\mathrm{CD} /$ chitosan resin & $m-$ & 200 & 39.9 & 30 & {$[32]$} \\
\hline$\beta$-CDP & $o-$ & 108 & 6.2 & 25 & This work \\
\hline$\beta$-CDP & $m-$ & 108 & 11.6 & 25 & This work \\
\hline$\beta$-CDP & $p$ - & 108 & 15.1 & 25 & This work \\
\hline
\end{tabular}

wastewater at $25^{\circ} \mathrm{C}$ [10], albeit with an inlet molar concentration fivefold higher than that used here. Another $\beta$-CDP synthesized by epichlorohydrin crosslinking yielded a sorption capacity for phenol of $5.51 \mathrm{mg} / \mathrm{g}$ in batch experiments at $25{ }^{\circ} \mathrm{C}[35]$.

\section{Desorption Experiments}

The elution profiles measured are very asymmetric, with the left-hand side increasing sharply to a maximum (at time $t_{\mathrm{M}}$ ) and then the right side decreasing smoothly and asymptotically to zero. Each profile showed this maximum concentration peak at around 5-10 min after turning on the eluent pump, and reaching several times the initial concentration value used in the corresponding sorption test (this maximum height is here defined as $\left.C / C_{0, \mathrm{M}}\right)$. The experimental data for the elution of the three isomers from the CDP beds were also successfully fitted (calculated determination coefficients, $\mathrm{R}^{2}>0.98$ ) to the pulse-peak model (Eq. 6). The results obtained are listed in Table 5: the independent parameters ( $c$ and $d$; therefore, also $\mathrm{N}-2$ degrees of freedom), the dependent variable $k$ (derived from the boundary condition given by Eq. 8), and the calculated values of peak time and peak height ( $t_{\mathrm{M}}$ and the $C / C_{0, \mathrm{M}}$, respectively). It is noteworthy that the average of the calculated $t_{\mathrm{M}}$ values did not vary significantly from one isomer to another: $8.02 \pm 0.36 \mathrm{~min}$ for $o$-cresol, $7.80 \pm 0.23 \mathrm{~min}$ for $m$-cresol, and $8.13 \pm 0.30 \mathrm{~min}$ for $p$-cresol. In contrast to $t_{\mathrm{M}}$, the $C / C_{0, \mathrm{M}}$ values obtained did appear to have a clear relationship with the sorption capacities of CDP found for each isomer. Thus, mean $C / C_{0, \mathrm{M}}$ values of $1.95 \pm 0.10$ were estimated for $o$-cresol, $3.72 \pm 0.22$ for $m$-cresol, and $4.96 \pm 0.27$ for $p$-cresol.

As illustrative examples, the experimental data of elution curves with the three eluents for the same operating cycle are shown in Fig. 3. The corresponding profiles calculated by Eq. (6) have been plotted for clarity. As was the case with the breakthrough curves, for each cresol isomer, very similar desorption profiles were found from test run 1 to 9 (see Fig. 3a for $m$-cresol). The effect of the type of sorbate on the elution profile is depicted for the same cycle (test run 3 ) in Fig. 3b. Despite the difference in amplitude in the profiles for each isomer, the time needed for achieving the desorption of the half amount of sorbate retained at each CDP bed was calculated to be relatively constant (between 13.5 and $14 \mathrm{~min}$ ). Again, a similar pattern was observed for each isomer and for each test run carried out.

Likewise, the structural appearance of the three CDP beds (one for each isomer tested) remained unchanged throughout the nine sorption-desorption cycles. The same finding was observed when almost up to thirty cycles with phenol 
Table 5 Fitting parameters of elution curves (test runs 1 to 9) of cresols from the CDP matrix

\begin{tabular}{llllllll}
\hline Run & $c\left(\mathrm{~min}^{-1}\right)$ & $d\left(\mathrm{~min}^{-2}\right)$ & $k(-)$ & $t_{\mathrm{M}}(\mathrm{min})$ & $C / C_{0, \mathrm{M}}$ & $\mathrm{SSE}(-)$ & $\mathrm{R}^{2}$ \\
\hline $\mathrm{oC} 1$ & 0.08067 & 0.03447 & 4.462 & 7.66 & 2.09 & 0.0490 & 0.9955 \\
$\mathrm{oC} 2$ & 0.07972 & 0.03108 & 4.445 & 7.98 & 2.03 & 0.0770 & 0.9881 \\
$\mathrm{oC} 3$ & 0.07961 & 0.03377 & 4.371 & 7.74 & 2.05 & 0.0559 & 0.9938 \\
$\mathrm{oC} 4$ & 0.07766 & 0.03251 & 4.234 & 7.90 & 1.99 & 0.0299 & 0.9982 \\
$\mathrm{oC5}$ & 0.07182 & 0.03696 & 3.770 & 7.69 & 1.93 & 0.0608 & 0.9920 \\
$\mathrm{oC6}$ & 0.07614 & 0.02646 & 4.175 & 8.46 & 1.86 & 0.0669 & 0.9898 \\
$\mathrm{oC7}$ & 0.07284 & 0.02930 & 3.917 & 8.35 & 1.86 & 0.0661 & 0.9899 \\
$\mathrm{oC} 8$ & 0.07301 & 0.03500 & 3.799 & 7.82 & 1.89 & 0.0615 & 0.9915 \\
$\mathrm{oC} 9$ & 0.07310 & 0.02697 & 4.029 & 8.60 & 1.86 & 0.0759 & 0.9869 \\
$\mathrm{mC} 1$ & 0.08402 & 0.03335 & 8.619 & 7.66 & 3.89 & 0.1253 & 0.9916 \\
$\mathrm{mC} 2$ & 0.07987 & 0.03082 & 8.035 & 7.99 & 3.65 & 0.1476 & 0.9870 \\
$\mathrm{mC} 3$ & 0.08971 & 0.03386 & 9.412 & 7.48 & 4.09 & 0.1285 & 0.9920 \\
$\mathrm{mC} 4$ & 0.08220 & 0.03629 & 8.206 & 7.48 & 3.85 & 0.1389 & 0.9885 \\
$\mathrm{mC5}$ & 0.08010 & 0.03430 & 8.114 & 7.68 & 3.81 & 0.1627 & 0.9851 \\
$\mathrm{mC6}$ & 0.07687 & 0.03196 & 7.717 & 7.97 & 3.63 & 0.1463 & 0.9883 \\
$\mathrm{mC7}$ & 0.08040 & 0.03085 & 8.231 & 7.98 & 3.73 & 0.1405 & 0.9885 \\
$\mathrm{mC} 8$ & 0.07038 & 0.03356 & 6.914 & 8.02 & 3.48 & 0.1589 & 0.9834 \\
$\mathrm{mC} 9$ & 0.06975 & 0.03447 & 6.607 & 7.96 & 3.37 & 0.1304 & 0.9880 \\
$\mathrm{pC} 1$ & 0.08656 & 0.02483 & 12.59 & 8.43 & 5.03 & 0.1053 & 0.9964 \\
$\mathrm{pC} 2$ & 0.08257 & 0.03000 & 12.31 & 8.00 & 5.43 & 0.1062 & 0.9968 \\
$\mathrm{pC} 3$ & 0.08034 & 0.02771 & 12.34 & 8.28 & 5.40 & 0.1652 & 0.9926 \\
$\mathrm{pC} 4$ & 0.07518 & 0.03404 & 10.22 & 7.84 & 4.97 & 0.1107 & 0.9959 \\
$\mathrm{pC5}$ & 0.07770 & 0.03308 & 10.08 & 7.85 & 4.76 & 0.1175 & 0.9951 \\
$\mathrm{pC6}$ & 0.07902 & 0.03408 & 10.03 & 7.73 & 4.74 & 0.1013 & 0.9963 \\
$\mathrm{pC7}$ & 0.08004 & 0.02735 & 11.01 & 8.34 & 4.81 & 0.1576 & 0.9915 \\
$\mathrm{pC} 8$ & 0.07959 & 0.02537 & 11.29 & 8.58 & 4.82 & 0.1583 & 0.9915 \\
$\mathrm{pC} 9$ & 0.08016 & 0.02962 & 10.56 & 8.10 & 4.73 & 0.1190 & 0.9949 \\
\hline
\end{tabular}

$o C o$-cresol, $m C m$-cresol, $p C p$-cresol were performed with other similar CDP bed [10], being that favorable condition attributed to the relative similarity in solvent polarities between methanol and water. Considering this fact, together with the adsorption capacities achieved, the present work demonstrates that CDPs would be good candidate materials to be used in multiple-cycle operations for the removal of cresols from water. Even though some other affordable materials, such as coconut charcoal, might show a better adsorption performance, the present investigation shows that these hydrogel sorbents are stable through successive sorption-desorption cycles.

\section{Conclusions}

The sorption of cresol isomers in packed beds composed of hydrogel beads of a cyclodextrin-based polymer and their regeneration have been studied for nine operating cycles. In addition, it has been shown that both Langmuir and Freundlich isotherms yield appropriate fittings in the range of conditions studied. Higher cresol concentrations in the batch experiments would be required to ascertain whether this material behaves as a homogeneous (i.e. Langmuir-like) one. Nevertheless, the sorption experiments carried out allowed to obtain the thermodynamic parameters of the process and confirm its exothermic nature with similar enthalpies for the three isomers. No significant different profiles for both sorption and desorption steps were observed under the experimental conditions applied. The mean sorption capacities of CDP beds were found to be $6.2 \mathrm{mg} / \mathrm{g}$-CDP for $o$-cresol, $11.6 \mathrm{mg} / \mathrm{g}$ for $m$-cresol, and $15.1 \mathrm{mg} / \mathrm{g}$ for $p$-cresol. Nevertheless, no substantial differences were observed in the sorption rates for each isomer, giving a mean value of about $0.10 \mathrm{mg}$-cresol g-CDP ${ }^{-1} \mathrm{~min}^{-1}$ in all systems. An analogous pattern was seen in the regeneration step, where half of the retained isomer on CDP bed was always released in a similar elution time (approximately $14 \mathrm{~min}$ ). The differences in cresol sorption capacities of the CDP are attributable to the different chemical structures of the isomers. The experimental data for the breakthrough and the elution curves have been successfully modeled by two effective two-parameter equations, a dose-response model for the sorption step and a 

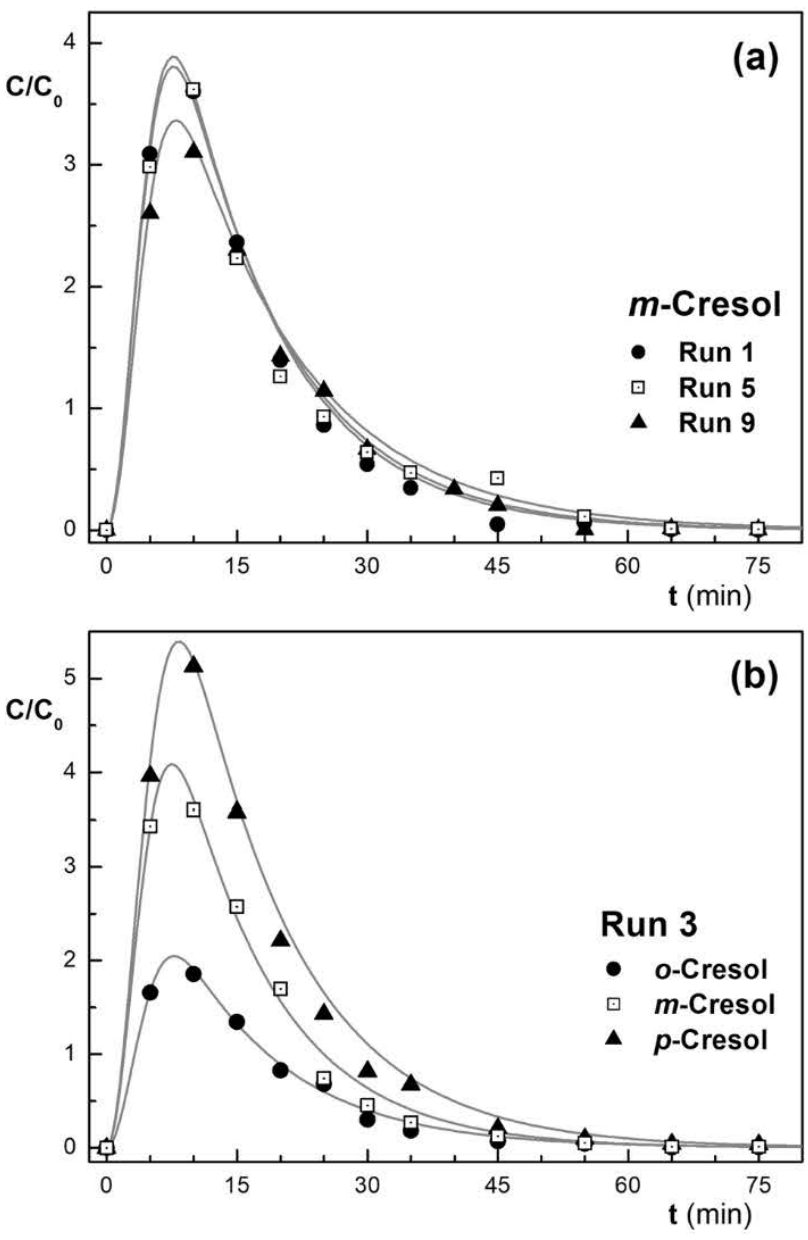

Fig. 3 Elution profiles of cresols from CDP beds: a for $m$-cresol desorption in test runs 1,5 and 9; $\mathbf{b}$ for the three isomers at test run 3

pulse-peak model for the regeneration step. The CDP matrix has been proven to be an effective a good sorbent material for removing cresols from water, exhibiting remarkable reusability performance and structural stability throughout the successive elution steps carried out with methanol.

Acknowledgements The authors are greatly thankful to University of Navarra (PIUNA Research Plan) and Friends of the University of Navarra Inc. for the financial aid.

Authors' Contributions JRI designed and supervised the experimental assays, and contributed to write the manuscript. AR carried out most of the experimental work. FJP performed the modeling of sorption and elution steps, and was a major contributor in writing the manuscript. All authors read and approved the final manuscript.

Funding Open Access funding provided thanks to the CRUE-CSIC agreement with Springer Nature.

\section{Declarations}

Conflict of interest The authors declare that they have no conflict of interest.

Ethical approval Not applicable.

Consent for publication Not applicable.

Data Availability The datasets generated and analysed during the current study are available from the corresponding author on reasonable request.

Open Access This article is licensed under a Creative Commons Attribution 4.0 International License, which permits use, sharing, adaptation, distribution and reproduction in any medium or format, as long as you give appropriate credit to the original author(s) and the source, provide a link to the Creative Commons licence, and indicate if changes were made. The images or other third party material in this article are included in the article's Creative Commons licence, unless indicated otherwise in a credit line to the material. If material is not included in the article's Creative Commons licence and your intended use is not permitted by statutory regulation or exceeds the permitted use, you will need to obtain permission directly from the copyright holder. To view a copy of this licence, visit http://creativecommons.org/licenses/by/4.0/.

\section{References}

1. Lin S, Zou C, Liang H, Peng H, Liao Y (2021) The effective removal of nickel ions from aqueous solution onto magnetic multi-walled carbon nanotubes modified by $\beta$-cyclodextrin. Colloids Surf A 619:126544. https://doi.org/10.1016/j.colsurfa.2021. 126544

2. Morin-Crini N, Winterton P, Fourmentin S, Wilson LD, Fenyvesi E, Crini G (2018) Water-insoluble $\beta$-cyclodextrin-epichlorohydrin polymers for removal of pollutants from aqueous solutions by sorption processes using batch studies: A review of inclusion mechanisms. Progress Polym Sci 78:1-23. https://doi.org/10. 1016/j.progpolymsci.2017.07.004

3. Seidi F, Jin Y, Xiao H (2020) Polycyclodextrins: synthesis, functionalization, and applications. Carbohydr Polym 242:116277. https://doi.org/10.1016/j.carbpol.2020.116277

4. Crini G (2021) Cyclodextrin-epichlorohydrin polymers synthesis, characterization and applications to wastewater treatment: a review. Environ Chem Lett. https://doi.org/10.1007/ s10311-021-01204-z

5. Peñas FJ, Sevillano X, Peñas MI (2019) Modeling of organic shock loading in a fluidized-bed bioreactor containing sorbent particles. Biochem Eng J 151:107308. https://doi.org/10.1016/j. bej. 2019.107308

6. Sevillano X, Isasi JR, Peñas FJ (2012) Performance of a fluidizedbed bioreactor with hydrogel biomass carrier under extremely low-nitrogen availability and effect of nitrogen amendments. J Chem Technol Biotechnol 87:402-409. https://doi.org/10.1002/ jetb. 2735

7. Crini G, Bertini S, Torri G, Naggi A, Sforzini D, Vecchi C, Janus L, Lekchiri Y, Morcellet M (1998) Sorption of aromatic compounds in water using insoluble cyclodextrin polymers. J Appl Polym Sci 68:1973-1978. https://doi.org/10.1002/(SICI)10974628(19980620)68:12\%3C1973::AID-APP11\%3E3.0.CO;2-T

8. Yamasaki H, Makihata Y, Kimitoshi Fukunaga K (2006) Efficient phenol removal of wastewater from phenolic resin plants using 
crosslinked cyclodextrin particles. J Chem Technol Biotechnol 81:1271-1276. https://doi.org/10.1002/jctb.1545

9. Tang W, Zou C, Da C, Cao Y, Peng H (2020) A review on the recent development of cyclodextrin-based materials used in oilfield applications. Carbohydr Polym 240:116321. https://doi.org/ 10.1016/j.carbpol.2020.116321

10. Peñas FJ, Romo A, Isasi JR, San José MJ, Alvarez S (2019) Kinetic modeling of sorption-desorption cycles for phenol removal with a cyclodextrin polymer. J Ind Eng Chem 75:93-99. https://doi.org/10.1016/j.jiec.2019.03.002

11. Duan W, Meng F, Cui H, Lin Y, Wang G, Wu J (2018) Ecotoxicity of phenol and cresols to aquatic organisms: A review. Ecotoxicol Environ Saf 157:441-456. https://doi.org/10.1016/j.ecoenv.2018. 03.089

12. Romo A, Peñas FJ, Sevillano X, Isasi JR (2006) Application of factorial experimental design to the study of the suspension polymerization of $\beta$-cyclodextrin and epichlorohydrin. J Appl Polymer Sci 100:3393-3402. https://doi.org/10.1002/app.23778

13. Rekharsky MV, Inoue Y (1998) Complexation thermodynamics of cyclodextrins. Chem Rev 98:1875-1917. https://doi.org/10.1021/ cr970015o

14. Majhi K, Khatun R, Jana S, Hajra A, Shukla A, Maiti P, Dey A, Ray PP, Sinha S (2018) Synthesis and characterization of hostguest inclusion complex of $m$-cresol with $\beta$-cyclodextrin. J Incl Phenom Macrocycl Chem 90:61-73. https://doi.org/10.1007/ s10847-017-0765-x

15. Romo A, Peñas FJ, Isasi JR, García-Zubiri IX, González-Gaitano G (2008) Extraction of phenols from aqueous solutions by $\beta$-cyclodextrin polymers. Comparison of sorptive capacities with other sorbents. React Funct Polym 68:406-413. https://doi.org/ 10.1016/j.reactfunctpolym.2007.07.005

16. Liu FQ, Xia MF, Yao SL, Li AM, Wu HS, Chen JL (2008) Adsorption equilibria and kinetics for phenol and cresol onto polymeric adsorbents: Effects of adsorbents/adsorbates structure and interface. J Hazar Mat 152:715-720. https://doi.org/10.1016/j. jhazmat.2007.07.071

17. Naef R (2019) Calculation of the Isobaric heat capacities of the liquid and solid phase of organic compounds at and around 298.15 $\mathrm{K}$ based on their "true" molecular volume. Molecules 24:1626. https://doi.org/10.3390/molecules24081626

18. Vasu AE (2008) Removal of phenol and $o$-cresol by adsorption onto activated carbon. J Chem 5:261637. https://doi.org/10.1155/ 2008/261637

19. Bakas I, Elatmani K, Qourzal S, Barka N, Assabbane A, Aît-Ichou I (2014) A comparative adsorption for the removal of $p$-cresol from aqueous solution onto granular activated charcoal and granular activated alumina. J Mater Environ Sci 5:675-682

20. Mourão PAM, Carrott PJM, Ribeiro-Carrott MML (2006) Application of different equations to adsorption isotherms of phenolic compounds on activated carbons prepared from cork. Carbon 44:2422-2429. https://doi.org/10.1016/j.carbon.2006.05.015

21. Thue PS, dos Reis GS, Lima EC, Sieliechi JM, Dotto GL, Wamba AGN, Dias SLP, Pavan FA (2017) Activated carbon obtained from sapelli wood sawdust by microwave heating for $o$-cresol adsorption. Res Chem Intermed 43:1063-1087. https://doi.org/10.1007/ s11164-016-2683-8

22. Jaafari J, Ghozikali MG, Azari A, Delkhosh MB, Javid AB, Mohammadi AA, Agarwal S, Gupta VK, Sillanpää M, Tkachev AG, Burakov AE (2018) Adsorption of $p$-cresol on $\mathrm{Al}_{2} \mathrm{O}_{3}$ coated multi-walled carbon nanotubes: Response surface methodology and isotherm study. J Ind Eng Chem 57:396-404. https://doi.org/ 10.1016/j.jiec.2017.08.048

23. Xu X, Chen X, Yang L, Zhao Y, Zhang X, Shen R, Sun D, Qian J (2020) Film-like bacterial cellulose based molecularly imprinted materials for highly efficient recognition and adsorption of cresol isomers. Chem Eng J 382:123007. https://doi.org/10.1016/j.cej. 2019.123007

24. Zhu Y, Kolar P (2016) Investigation of adsorption of $p$-cresol on coconut shell-derived activated carbon. J Taiwan Inst Chem Eng 68:138-146. https://doi.org/10.1016/j.jtice.2016.07.044

25. Hadjar H, Hamdi B, Ania CO (2011) Adsorption of $p$-cresol on novel diatomite/carbon composites. J Hazard Mater 188:304-310. https://doi.org/10.1016/j.jhazmat.2011.01.108

26. Ooi CH, Ling YP, Pung SY, Yeoh FY (2019) Mesoporous hydroxyapatite derived from surfactant-templating system for $p$-cresol adsorption: Physicochemical properties, formation process and adsorption performance. Powder Technol 342:725-734. https://doi.org/10.1016/j.powtec.2018.10.043

27. Cao G, Gao M, Shen T, Zhao B, Zeng H (2019) Comparison between asymmetric and symmetric gemini surfactant-modified novel organo-vermiculites for removal of phenols. Ind Eng Chem Res 58:12927-12938. https://doi.org/10.1021/acs.iecr.9b02997

28. Sharma G, Kumar A, Chauhan C, Okram A, Sharma S, Pathania D, Kalia S (2017) Pectin-crosslinked-guar gum/SPION nanocomposite hydrogel for adsorption of $m$-cresol and o-chlorophenol. Sustain Chem Pharm 6:96-106. https://doi.org/10.1016/j.scp. 2017.10.003

29. Huang $\mathbf{J}$ (2009) Treatment of phenol and $p$-cresol in aqueous solution by adsorption using a carbonylated hypercrosslinked polymeric adsorbent. J Hazard Mater 168:1028-1034. https://doi.org/ 10.1016/j.jhazmat.2009.02.141

30. Li Y, Bi HY, Jin YS (2017) Facile preparation of rhamnolipidlayered double hydroxide nanocomposite for simultaneous adsorption of $p$-cresol and copper ions from water. Chem Eng J 308:78-88. https://doi.org/10.1016/j.cej.2016.09.030

31. Li X (2014) Adsorption of $m$-cresol from aqueous solutions by $\beta$-cyclodextrin polymer. Fresenius Environ Bull 23:1485-1489

32. Chen QY, Xiao JB, Chen XQ, Jiang XY, Yu HZ, Xu M (2006) The adsorption of phenol, $m$-cresol and $m$-catechol on a $\beta$-cyclodextrin derivative-grafted chitosan and the removal of phenols from industrial wastewater. Adsorp Sci Technol 24:547-557. https:// doi.org/10.1260/026361706780810230

33. El-Naas MH, Alhaija MA, Al-Zuhair S (2017) Evaluation of an activated carbon packed bed for the adsorption of phenols from petroleum refinery wastewater. Environ Sci Pollut Res 24:75117520. https://doi.org/10.1007/s11356-017-8469-8

34. Peng H, Zou C, Wang C, Tang W, Zhou J (2020) The effective removal of phenol from aqueous solution via adsorption on $\mathrm{CS} / \beta-\mathrm{CD} / \mathrm{CTA}$ multicomponent adsorbent and its application for COD degradation of drilling wastewater. Environ Sci Pollut Res 27:33668-33680. https://doi.org/10.1007/s11356-020-09437-1

35. Cai S, Luo J, Liu H (2017) Preparation of $\beta$-cyclodextrin polymer by inverse-phase suspension polymerization and its capability for phenol removal. Key Eng Mater 730:195-199

Publisher's Note Springer Nature remains neutral with regard to jurisdictional claims in published maps and institutional affiliations. 